\title{
Information Richness, Retailer Brand, Extended Offers pada Niat Beli Konsumen Menggunakan T-Cash
}

\author{
Alit Trihernindya Koesetyo Putri, Bustanul Arifin Noer, dan Satria Fadil Persada \\ Jurusan Manajemen Bisnis, Fakultas Teknologi Industri, Institut Teknologi Sepuluh Nopember (ITS) \\ Jl. Arief Rahman Hakim, Surabaya 60111 Indonesia \\ e-mail: bus4arifin@gmail.com
}

\begin{abstract}
Abstrak-Pada era yang menuntut serba cepat dan instan, pembayaran elektronik memberikan kemudahan dan kecepatan dalam bertransaksi. Dari berbagai macam jenis pembayaran elektronik, Telkomsel T-Cash muncul sebagai jenis pembayaran elektronik berupa uang elektronik untuk menyimpan uang dan bertransaksi saat membeli produk di merchant atau peritel. Konsumen hanya perlu memiliki stiker T-Cash yang diletakkan di smartphone kemudian menempalkannya (tap) ke mesin NFC yang tersedia di merchant. Meski demikian, jumlah pengguna T-Cash masih belum mencapai target, sehingga Telkomsel perlu memperhatikan faktor-faktor yang mempengaruhi niat beli konsumen menggunakan T-Cash. Melalui penyebaran kuesioner ditujukan kepada pengguna $\mathrm{T}$-Cash, penelitian ini bertujuan untuk meneliti pengaruh faktor information richness, retailer brand, extended offers, serta pengaruh hubungan ketiganya pada niat beli konsumen menggunakan T-Cash. Hierarchical moderator regression analysis, simple slope analysis dan structural equation modelling (SEM) digunakan sebagai metode penelitian dengan confirmatory factor analysis untuk melakukan studi konfirmasi terhadap penelitian terdahulu. Penelitian ini menunjukkan bahwa ketiga faktor berpengaruh positif terhadap niat beli konsumen mengunakan T-Cash, information richness berhubungan komplemen dengan extended offers, extended offers menjadi substitusi retailer brand, serta information richness dengan retailer brand berhubungan substitusi dalam meningkatkan niat beli menggunakan T-Cash. Disarankan untuk penelitian selanjutnya dapat menyelidiki pengaruh faktor lainnya serta diaplikasikan pada jenis layanan yang lebih bervariasi.
\end{abstract}

Kata Kunci-extended offers, information richness, niat beli konsumen, retailer brand, uang elektronik

\section{PENDAHULUAN}

$\mathrm{P}$ EMBAYARAN elektronik menjadi metode pembayaran yang popular untuk transaksi jual beli online, terutama pada perdagangan elektronik atau electronic commerce (ecommerce). Pertumbuhan internet mendukung popularitas metode pembayaran ini, sebagaimana e-commerce telah membawa dampak baru pada kebutuhan finansial, yang mana tidak efektif jika dilakukan menggunakan metode pembayaran tradisional [1]. Pembayaran elektronik seperti internet banking, mobile banking, dan e-money memberi kenyamanan, keamanan, kecepatan, fleksibilitas, dan keuntungan saat bertransaksi [1]-[4]. T-Cash merupakan layanan e-money dari Telkomsel berupa aplikasi penyimpan uang, serta alat transaksi
Near Field Communication (NFC) berupa stiker yang diletakkan di smartphone, lalu menempelkannya (tap) di mesin NFC merchant. T-Cash dirilis sebagai dukungan Gerakan Nasional Non Tunai (GNNT), dan bekerjasama dengan peritel seperti McDonald's, KFC, dan Cinema XXI. Meski demikian, hingga awal tahun 2016, Telkomsel belum mencapai target pengguna T-Cash, tercatat hanya 6 juta pengguna aktif yang memanfaatkan layanan ini untuk transaksi.

Penelitian terdahulu telah meneliti niat beli konsumen pada e-commerce dipengaruhi oleh faktor kelengkapan informasi atau information richness, merek peritel, penawaran ekstra atau extended offers [5]. Faktor-faktor tersebut merupakan faktor eksternal, sedangkan pengunaan pembayaran elektronik banyak dipengaruhi oleh faktor internal seperti perceived usefulness, perceived trust, perceived ease of use [2]-[4]. Masih sedikit yang meneliti pengaruh faktor-faktor eksternal terhadap niat beli konsumen menggunakan pembayaran elektronik, seperti informasi produk, merek peritel, dan penawaran ekstra. Penelitian ini akan membahas celah tersebut sebagai permasalahan dan tujuan penelitian berikut:

1) Pengaruh information richness, retailer brand, extended offers terhadap niat beli konsumen menggunakan T-Cash.

2) Pengaruh hubungan komplemen dan substitusi antara information richness, retailer brand, extended offers terhadap niat beli konsumen menggunakan T-Cash.

\section{LANDASAN TEORI}

\section{A. Electronic Money}

Electronic money (e-money) atau uang elektronik merupakan alat pembayaran elektronik yang memberikan kemudahan untuk bertransaksi melalui perangkat teknologi seperti smartphone [4]. Pembayaran elektronik mewakili seluruh pembayaran non-tunai, diartikan pula sebagai transaksi elektronik dari pembeli ke penerima melalui sebuah akun tabungan menggunakan jaringan elektronik [1].

\section{B. Niat Beli Konsumen}

Dalam ilmu pemasaran, terdapat empat tahapan respon konsumen, yaitu awareness, interest, desire, action yang sering disebut dengan teori AIDA [6]. Niat beli konsumen tergolong tahap interest, yaitu saat konsumen tertarik pada sebuah 
produk. Tahap ini muncul setelah awareness yaitu tahap menarik perhatian konsumen pada sebuah produk. Niat beli konsumen diartikan sebagai respon perilaku konsumen terhadap faktor rangsangan [7]. Faktor yang dapat memepengaruhi niat beli konsumen anatara lain reputasi peritel [7], [8], citra merek [9], informasi produk [10]-[12], dan penawaran ekstra [13], serta hubungan komplemen dan substitusi antar faktor-faktor tersebut [5].

\section{Information Richness}

Information richness adalah informasi produk yang disampaikan peritel melalui berbagai media komunikasi kepada konsumen berupa tulisan, gambar, suara, dan video [5], [14]. Informasi produk yang lengkap dapat membantu konsumen memperoleh deskripsi dan spesifikasi produk, dan untuk memastikan kualitas produk yang akan dibeli [5], [15], [16]. Makin lengkap informasi produk, makin berpengaruh positif pada kepuasan konsumen terhadap informasi produk, serta meningkatkan niat beli konsumen [12]. Dengan demikian, information richness merupakan salah satu faktor yang mendorong niat beli konsumen menggunakan T-Cash.

\section{Retailer Brand}

Retailer brand atau merek peritel adalah faktor penting sebagai pertimbangan saat akan membeli produk, sebab merek peritel yang terkenal dapat mengurangi keraguan konsumen dan membantu membangun kepercayaan konsumen [5], [17]. Merek peritel yang terkenal dapat diukur berdasarkan citra atau reputasi toko sebab berpengaruh signifikan pada respon dan perilaku konsumen [8], [18]. Makin mudah konsumen mengingat merek, makin tinggi niat pembelian [19]. Dengan demikian, retailer brand menjadi faktor penting yang mendorong niat beli konsumen menggunakan T-Cash.

\section{E. Extended offers}

Extended offers diartikan sebagai layanan tambahan berupa penawaran ekstra untuk menciptakan value (nilai) dan experience (pengalaman) saat konsumen melakukan pembelian [5], [20]. Penawaran berupa promosi harga, diskon, dan kupon dapat membantu menarik calon konsumen potensial [21]. Hal ini menjadi faktor pendorong niat beli konsumen dengan tujuan mengurangi risiko biaya, waktu, dan usaha saat transaksi [1]. Makin menarik penawaran, makin besar niat beli konsumen menggunakan T-Cash.

\section{F. Hubungan Information Richness dan Retailer Brand}

Pada tahap awal pembelian, konsumen menilai merek peritel terlebih dahulu, kemudian melihat informasi produk untuk mengevaluasi kualitas produk. Hal ini disebut sebagai pengaruh konfirmasi (confirmation effect) yang umumnya terjadi pada experiential purchasing seperti pembelian makanan dan pakaian [22]. Hubungan antara information richness dan retailer brand dapat digolongkan hubungan komplemen karena pengaruh kedua faktor tersebut sama besarnya, maka keduanya saling melengkapi dalam meningkatkan niat beli konsumen. Makin lengkap informasi produk, maka dapat melengkapi pengaruh merek peritel dalam meningkatkan niat beli konsumen menggunakan T-Cash.

\section{G. Hubungan Information Richness dan Extended Offers}

Information richness berperan sebagai layanan inti, sedangkan extended offers adalah layanan tambahan sebagai pelengkap dari informasi produk [5], [20]. Confirmation effect juga terjadi dalam hubungan keduanya, sebab konsumen memanfaatkan informasi produk untuk menemukan produk yang diinginkan, sementara penawaran ekstra mendorong terjadinya pembelian langsung, karena faktor ini membuat proses pembelian lebih menguntungkan [22]. Keduanya berpengaruh besar terhadap niat beli konsumen, sehingga extended offers dan information richness dapat saling melengkapi atau hubungan komplemen dalam meningkatkan niat beli konsumen menggunakan T-Cash.

\section{H. Hubungan Extended Offers dan Retailer Brand}

Selain merek peritel, konsumen juga memiliki preferensi untuk memperoleh keuntungan moneter secara tidak terduga saat berbelanja berupa penawaran diskon, bonus, dan lainnya [23]. Penawaran ekstra dapat meningkatkan niat beli konsumen walaupun merek peritel kurang dikenal, sehinga beberapa konsumen memilih extended offers daripada kualitas atau merek peritel [5], [21]. Apabila merek peritel kurang dikenal, peritel perlu memberikan penawaran ekstra untuk menarik pelanggan. Dengan demikian, extended offers menjadi substitusi retailer brand dalam meningkatkan niat beli konsumen menggunakan T-Cash, jika merek kurang dikenal.

\section{METODE PENELITIAN}

Penelitian ini menguji 6 hipotesis dengan model penelitian ditunjukkan Gambar 1 diolah dari penelitian Yen [5]. Keenam hipotesis yang diuji adalah:

H1. Information richness berpengaruh positif pada niat beli konsumen menggunakan T-Cash.

$\mathrm{H} 2$. Retailer brand berpengaruh positif pada niat beli konsumen menggunakan T-Cash.

H3. Extended offers berpengaruh positif pada niat beli konsumen menggunakan T-Cash.

H4. Information richness melengkapi retailer brand dalam meningkatkan niat beli konsumen menggunakan T-Cash, peritel dengan information richness yang tinggi akan meningkatkan pengaruh niat beli konsumen menggunakan T-Cash jika merek peritel terkenal.

H5. Extended offers melengkapi information richness dalam meningkatkan niat beli konsumen menggunakan T-Cash, peritel dengan extended offers yang tinggi akan meningkatkan pengaruh niat beli konsumen menggunakan T-Cash jika information richness tinggi.

H6. Extended offers menjadi subtitusi retailer brand dalam meningkatkan niat beli konsumen menggunakan T-Cash, peritel dengan extended offers yang tinggi akan meningkatkan pengaruh niat beli konsumen menggunakan T-Cash walaupun merek peritel kurang dikenal. 


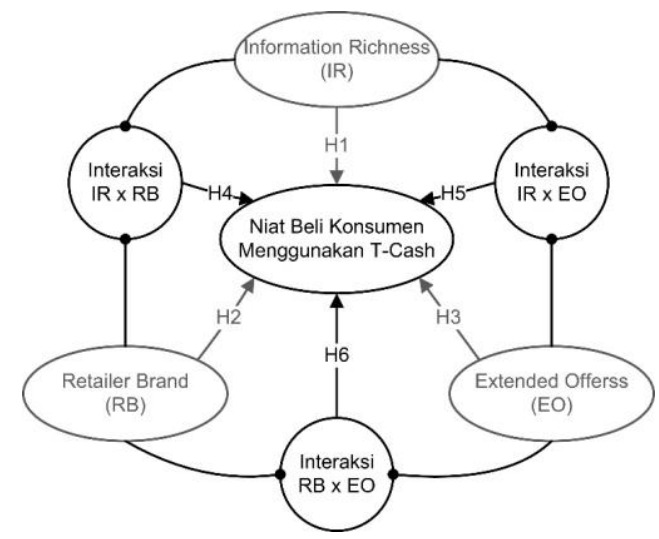

Gambar. 1. Model penelitian pengaruh information richness, retailer brand, extended offers, serta interaksi ketiganya terhadap niat beli konsumen menggunakan T-Cash.

Pengujian model pada hipotesis 1, 2, dan 3 menggunakan metode structural equation modeling (SEM), sedangkan hipotesis 4, 5, 6 diuji menggunakan hierarchical moderator regression analysis dan simple slope analysis.

Tabel 1.

Instrumen Pernyataan Kuesioner

\begin{tabular}{|c|c|c|}
\hline Variabel & Dimensi & Sumber \\
\hline \multirow{5}{*}{$\begin{array}{l}\text { Information } \\
\text { Richness } \\
\text { (IR) }\end{array}$} & IR1. T-Cash memungkinkan konsumen untuk & [5] \\
\hline & memperoleh banyak informasi dan manfaat & \\
\hline & $\begin{array}{l}\text { IR2. T-Cash menyediakan berbagai macam bentuk } \\
\text { informasi dan pelayanan }\end{array}$ & \\
\hline & $\begin{array}{l}\text { IR3. T-Cash menyediakan informasi dan pelayanan } \\
\text { produk yang relevan }\end{array}$ & [10] \\
\hline & $\begin{array}{l}\text { IR4. T-Cash menyediakan informasi dan pelayanan } \\
\text { produk yang konsisten }\end{array}$ & \\
\hline \multirow[t]{4}{*}{$\begin{array}{l}\text { Retailer } \\
\text { Brand (RB) }\end{array}$} & $\begin{array}{l}\text { RB1. T-Cash adalah produk dari perusahaan besar } \\
\text { yang semua orang kenali }\end{array}$ & [18] \\
\hline & RB2. T-Cash memiliki reputasi yang bagus & \\
\hline & RB3. T-Cash merupakan produk yang terkenal & \\
\hline & $\begin{array}{l}\text { RB4. Konsumen pernah mengalami menggunakan T- } \\
\text { Cash }\end{array}$ & $-[5]$ \\
\hline \multirow[t]{4}{*}{$\begin{array}{l}\text { Extended } \\
\text { Offers (EO) }\end{array}$} & $\begin{array}{l}\text { EO1. Diskon dan promosis yang ada di T-Cash } \\
\text { membuat konsumen nyaman dan percaya diri }\end{array}$ & [5] \\
\hline & $\begin{array}{l}\text { EO2. T-Cash mendukung promosi tambahan di } \\
\text { sekitar konsumen sejak pertama kali ada }\end{array}$ & \\
\hline & $\begin{array}{l}\text { EO3. Proses pembayaran dan pengisian T-Cash } \\
\text { tersedia dan cukup nyaman }\end{array}$ & \\
\hline & $\begin{array}{l}\text { EO4. T-Cash bekerja sama dalam hal promosi } \\
\text { dengan merchant atau peritel }\end{array}$ & [21] \\
\hline \multirow{4}{*}{$\begin{array}{l}\text { Niat Beli } \\
\text { Konsumen } \\
\text { (NBK)T- } \\
\text { Cash }\end{array}$} & $\begin{array}{l}\text { NBK1. Jika konsumen bisa, konsumen ingin } \\
\text { membeli produk dengan menggunakan T-Cash }\end{array}$ & [5] \\
\hline & $\begin{array}{l}\text { NBK2. Dimungkinkan konsumen akan membeli } \\
\text { produk dengan T-Cash di waktu mendatang }\end{array}$ & \\
\hline & $\begin{array}{l}\text { NBK3. Konsumen berminat membeli produk dengan } \\
\text { T-Cash di waktu mendatang }\end{array}$ & \\
\hline & $\begin{array}{l}\text { NBK4. Konsumen akan membeli produk yang } \\
\text { konsumen lihat ada layanan T-Cash di waktu } \\
\text { mendatang }\end{array}$ & [18] \\
\hline
\end{tabular}

Penelitian ini megumpulkan data melalui penyebaran kuesioner secara offline dan online di Surabaya dengan convenience sampling method. Kuesioner terdiri dari tiga bagian. Pertama screening untuk menentukan responden yang lolos kriteria sampel yaitu pengguna T-Cash, kedua demografi responden, ketiga berupa persetujuan dari instrumen pernyataan yang ditunjukkan pada Tabel 1 , menggunakan skala likert 5 (lima) poin, yaitu poin 1 (satu) sangat tidak seuju, hingga poin 5 (lima) sangat setuju. Pengumpulan data mulai 11 November - 10 Desember 2016 dan terkumpul 214 kuesioner lolos screening dari 234 yang tersebar, yang kemudian dilakukan analisis data.

\section{HASIL DAN DISKUSI}

\section{A. Demografi}

Demografi responden terdiri dari jenis kelamin, usia, pendidikan terakhir, dan pekerjaan. Dari 214 respon, 138 responden perempuan dan 76 laki-laki. Sebanyak 200 responden berusia 18-24 tahun, sedangkan usia 25-34 tahun dan 45-54 tahun masing-masing sebanyak 12 dan 2 responden. Pendidikan terakhir sekolah menengah sebanyak 138 responden, 72 bergelar sarjana, serta magister sebanyak 4 responden. Pekerjaan responden sebanyak 182 adalah pelajar atau mahasiswa, diikuti oleh pegawai dan wirausaha secara berurutan 16 dan 4 responden, serta 12 pekerjaan lainnya seperti ibu rumah tangga dan fresh graduate sebanyak.

\section{B. Analisis Model Penelitian SEM}

Penelitian ini melakukan uji model penelitian SEM menggunakan respesifikasi model dengan motode eliminasi untuk memperoleh model penelitian yang paling sesuai dengan data. Metode eliminasi dilakukan dengan mengurangi indikator tertentu untuk memperoleh nilai factor loadings yang memenuhi nilai minimum. dengan menghilangkan RB1, RB3, EO1, dan EO3, sehingga respesifikasi model ini dilakukan pengujian validitas, reliabilitas, serta model fit.

Tabel 2.

Uji validitas dan reliabilitas

\begin{tabular}{lcccc}
\hline \hline & \multicolumn{3}{c}{ Validitas } & Reliabilitas \\
\cline { 2 - 5 } & $\begin{array}{c}\text { Factor } \\
\text { Loadings } \\
(\geq 0.60)\end{array}$ & $\begin{array}{c}\text { AVE } \\
(\geq 0.50)\end{array}$ & $\begin{array}{c}\text { Composite } \\
\text { Reliability } \\
(\geq 0.70)\end{array}$ & $\alpha(\geq 0.70)$ \\
\hline Inormation Richness & & 0.54 & 0.82 & 0.82 \\
IR1 & 0.78 & & & \\
IR2 & 0.76 & & & \\
IR3 & 0.72 & & & \\
IR4 & 0.66 & & 0.71 & 0.77 \\
Retailer Brand & & 0.55 & & \\
RB2 & 0.64 & & & \\
RB4 & 0.83 & & 0.73 & 0.76 \\
Extended Offers & & 0.58 & & \\
EO2 & 0.74 & & & \\
EO4 & 0.78 & & & \\
Niat Beli Konsumen & & 0.71 & 0.91 & \\
NBK1 & 0.81 & & & \\
NBK2 & 0.91 & & & \\
NBK3 & 0.89 & & & \\
NBK4 & 0.74 & & & \\
Data dianalisis & & & \\
& & & & \\
\end{tabular}

Data dianalisis mengunakan confirmatory factor analysis (CFA) yang diolah dengan software AMOS untuk menguji validitas konvergen dan validitas diskriminan melalui nilai factor loadings (FL), composite reliability (CR), dan average 
variance extracted (AVE). Variabel penelitian dikatakan valid apabila nilai FL melebihi 0.60 , CR melebihi 0.70 , dan AVE melebihi 0.50 [24], [25]. Uji reliabilitas menggunakan software SPSS untuk mengetahui nilai Cronbach's $\alpha$ lebih dari 0.70 dapat dikatakan reliabel [26]. Tabel 2 menunjukkan bahwa data memenuhi uji validitas dan reliabilitas.

Uji model fit dilakukan menggunakan software AMOS untuk mengukur kelayakan model penelitian atau goodness of fit (GOF). Nilai yang memenuhi adalah Goodness of Fit Index (GFI), Normed Fit Index (NFI), Comparative Fit Index (CFI), Increment Fit Index (IFI), dan Tucker-Lewis Index (TLI) yaitu lebih dari 0.80 menunjukkan model penelitian memenuhi uji kelayakan model.

Analisis uji model dan hipotesis SEM diolah menggunakan software AMOS untuk menguji hipotesis 1, 2, 3 layak dan dapat diterima. Pengujian menggunakan pendekatan bootstrap dengan estimasi maximum likelihood untuk memperoleh hasil yang signifikan ketika ukuran sampel relatif kecil (kurang dari 400). Pengujian hipotesis SEM ditunjukkan pada Tabel 3.

Tabel 3.

Uji hipotesis SEM

\begin{tabular}{llll}
\hline \hline Variabel & Correlation $(\beta)$ & Significance $(\mathrm{p})$ & Hipotesis \\
\hline $\mathrm{NBK} \leftarrow \mathrm{IR}$ & 0.25 & $0.003^{* * *}$ & H1 diterima \\
$\mathrm{NBK} \leftarrow \mathrm{RB}$ & 0.66 & $0.002^{* * *}$ & $\mathrm{H} 2$ diterima \\
$\mathrm{NBK} \leftarrow \mathrm{EO}$ & 0.34 & $0.002^{* * *}$ & H3 diterima
\end{tabular}

$* * * \mathrm{p} \leq 0.001 ; \mathrm{NBK}\left(\mathrm{R}^{2}\right)=0.609$

Nilai $R$-square NBK mencapai 60 persen $\left(\mathrm{R}^{2}=0.609\right)$, menunjukkan bahwa prediktor niat beli konsumen menggunakan T-Cash menjelaskan 60.9 persen dari variansnya. Information richness $(\mathrm{p}=0.003 ; \beta=0.25)$, retailer brand $(\mathrm{p}=0.002 ; \quad \beta=0.66)$, extended offers $(\mathrm{p}=0.002 ; \quad \beta=0.34)$ berpengaruh positif secara signifikan terhadap niat beli konsumen menggunakan $\mathrm{T}$-Cash, dengan retailer brand berkorelasi paling besar yaitu 66 persen. Dengan demikian hipotesis 1, 2, 3 pada model penelitian SEM diterima.

\section{Hierarchical Moderator Regression Analysis}

Analisis ini digunakan untuk menguji pengaruh interaksi antara information richness, retailer brand, dan extendedd offers terhadap niat beli konsumen menggunakan T-Cash yang diolah melalui software SPSS untuk menguji hipotesis 4, 5, dan 6. Berikut persamaan regresi bersumber dari penelitian Yen [5]:

$$
\mathrm{Y}=\alpha+\beta 1 \mathrm{X} 1+\beta 2 \mathrm{X} 2+\beta 3 \mathrm{X} 3+\beta 4 \mathrm{X} 1 \mathrm{X} 2+\beta 5 \mathrm{X} 1 \mathrm{X} 3+\beta
$$
$6 \mathrm{X} 2 \mathrm{X} 3+\varepsilon$

$\mathrm{Y}$ adalah niat beli konsumen, $\mathrm{X} 1$ adalah information richness, $\mathrm{X} 2$ retailer brand, $\mathrm{X} 3$ extended offers, $\alpha$ merupakan konstanta, $\beta 1-6$ koefisien regresi, dan $\varepsilon$ standard error.

Analisi ini menggunakan teknik least squares untuk menguji tiga tahap iterasi. Tabel 4 menunjukkan hasil analisis dengan control variables pada tahap pertama adalah jenis kelamin dan usia, dilanjutkan dengan main effects adalah information richness, retailer brand, dan extended offers, serta interactions pada tahap ketiga.
Pengujian control variables mengindikasi bahwa jenis kelamin $(\mathrm{B}=0.111 ; \mathrm{P}=0.104)$ dan usia $(\mathrm{B}=0.108 ; \mathrm{P}=0.113)$ berpengaruh positif namun tidak signifikan terhadap niat beli konsumen menggunakan T-Cash. Nilai $R$-square $\left(\mathrm{R}^{2}=0.025\right)$ menunjukkan hanya 2.5 persen varians pada variabel outcome dapat dijelaskan oleh variabel prediktor.

Tabel 4.

Hierarchical moderator regression analysis

\begin{tabular}{lllc}
\multicolumn{4}{c}{ Hierarchical moderator regression analysis } \\
\hline \multicolumn{1}{c}{ Step } & Variabel prediktor & Correlation $(\mathrm{B})$ & Sig. $(\mathrm{P})$ \\
\hline Control & Jenis Kelamin & 0.111 & 0.104 \\
Variables & Usia & 0.108 & 0.113 \\
& $\mathrm{R}^{2}$ & 0.025 & \\
Main Efects & Jenis Kelamin & 0.076 & 0.090 \\
& Usia & $0.126^{* *}$ & 0.005 \\
& Information richness (IR) & $0.185^{* *}$ & 0.001 \\
& Retailer brand (RB) & $0.466^{* *}$ & 0.000 \\
& Extended offers (EO) & $0.236^{* *}$ & 0.000 \\
& $\mathrm{R}^{2}$ & 0.590 & \\
Interactions & Jenis Kelamin & 0.079 & 0.093 \\
& Usia & $0.114^{*}$ & 0.013 \\
& IR & $0.200^{* *}$ & 0.000 \\
& RB & $0.425^{* *}$ & 0.000 \\
& EO & $0.214^{* *}$ & 0.000 \\
& IR x RB & -0.096 & 0.184 \\
& IR x EO & 0.038 & 0.636 \\
& RB x EO & -0.030 & 0.723 \\
& $\mathrm{R}^{2}$ & 0.597 & \\
\hline \hline
\end{tabular}

$* \mathrm{P}<0.05: * * \mathrm{P}<0.01$

Pengujian main effects mengindikasi bahwa information richness $(\mathrm{B}=0.185 ; \quad \mathrm{P}=0.001)$, retailer brand $(\mathrm{B}=0.466$; $\mathrm{P}=0.000)$, dan extended offers $(\mathrm{B}=0.236 ; \quad \mathrm{P}=0.000)$ berpengaruh positif terhadap niat beli konsumen menggunakan T-Cash. Nilai $R$-square $\left(\mathrm{R}^{2}=0.590\right)$ menunjukkan bahwa 59 persen varians pada niat beli konsumen menggunakan T-Cash dapat dijelaskan oleh variabel prediktor. Hal ini serupa dengan hasil uji model dan hipotesis SEM.

Pengujian interaksi mengindikasi hubungan information richness dengan retailer brand $(\mathrm{B}=-0.096 ; \quad \mathrm{P}=0.184)$ berpengaruh signifikan negatif menunjukkan bahwa keduanya tidak berkomplemen sehingga Hipotesis 4 ditolak. Hubungan information richness dengan extended offers $(\mathrm{B}=0.038$; $\mathrm{P}=0.636$ ) berpengaruh signifikan positif menunjukkan bahwa keduanya berkomplemen sehingga Hipotesis 5 diterima. Hubungan retailer brand dengan extended offers $(\mathrm{B}=-0.030$; $\mathrm{P}=0.723$ ) berpengaruh siginifikan negatif menunjukkan bahwa keduanya berhubungan substitusi sehingga Hipotesis 6 diterima. Nilai $R$-square $\left(\mathrm{R}^{2}=0.597\right)$ menunjukkan bahwa 59,7 persen varians pada niat beli konsumen menggunakan T-Cash dapat dijelaskan oleh variabel prediktor.

\section{Simple Slope Analysis}

Pengujian hipotesis 4, 5, dan 6 dilakukan melalui two-way interaction effects menggunakan simple slope analysis yang dikembangkan oleh Aiken dan West untuk meneliti hubungan antara variabel independen dan variabel dependen yang dimoderasi oleh variabel indpenden lainnya [5]. Tujuannya untuk mengetahui hubungan komplemen dan substitusi antara inormation richness, retailer brand, dan extended offers berdasarkan tinggi rendahnya pengaruh faktor dalam meningkatkan niat beli konsumen menggunakan T-Cash. 
Tinggi rendahnya suatu faktor ditentukan dengan mengambil satu nilai standar deviasi di atas (tinggi) dan di bawah (rendah) nilai mean faktor tersebut [27].

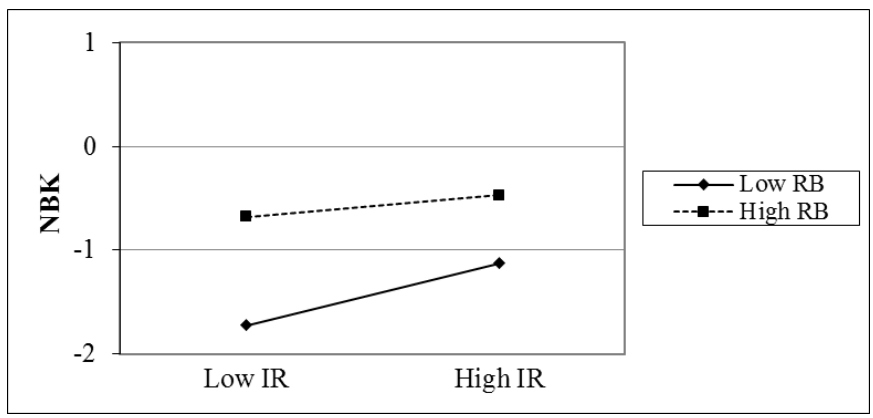

Gambar. 2. Interaksi information richness dengan retailer brand terhadap niat beli konsumen menggunakan T-Cash.

Interaksi antara information richness (IR) dengan retailer brand (RB) ditunjukkan pada Gambar 2 dengan dua garis nonparalel bersifat konvergen atau saling bertemu pada satu titik. Hal ini menunjukkan bahwa tidak terjadi hubungan komplemen antara keduanya dalam meningkatkan niat beli konsumen menggunakan T-Cash. Hubungan antara information richness dengan retailer brand cenderung berhubungan substitusi, sehingga Hipotesis 4 ditolak.

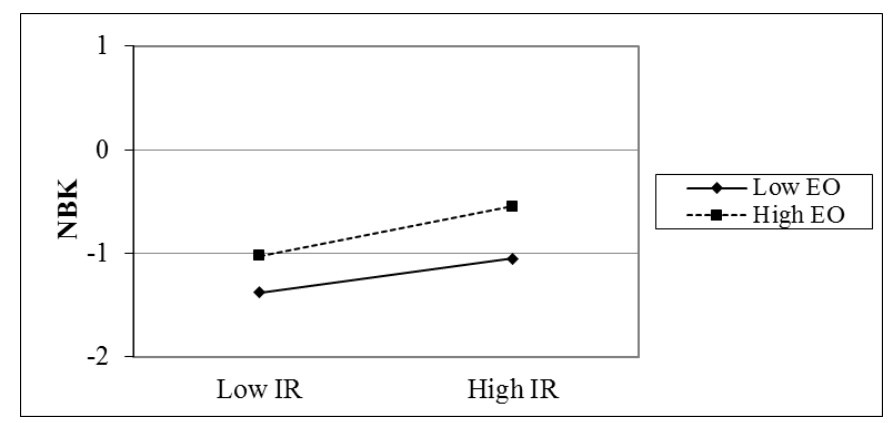

Gambar. 3. Interaksi information richness dengan extended offers terhadap niat beli konsumen menggunakan T-Cash.

Interaksi antara information richness (IR) denan extended offers (EO) ditunjukkan pada Gambar 3 dengan dua garis nonparalel mengalamai kecenderungan untuk difusi atau menyebar. Hal ini menunjukkan hubungan antara information richness dengan extended offers merupakan hubungan komplemen, sehingga Hipotesis 5 diterima.

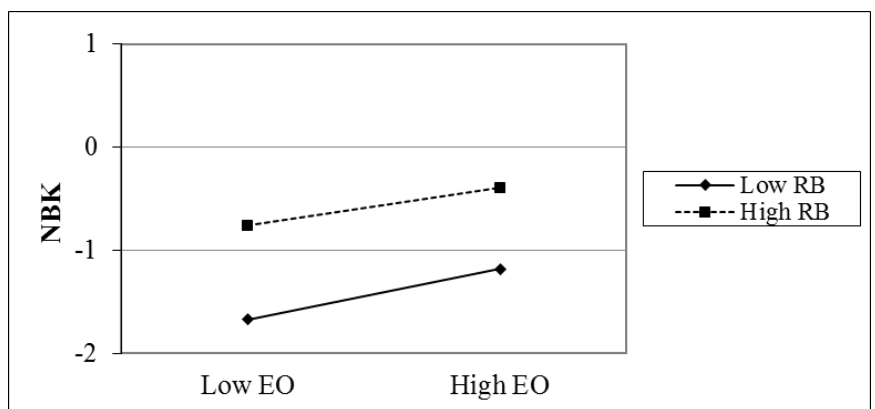

Gambar. 4. Interaksi retailer brand dengan extended offers terhadap niat beli konsumen menggunakan T-Cash.

Interaksi antara retailer brand (RB) dengan extended offers (EO) ditunjukkan pada Gambar 4 dengan dua garis nonparalel mengalamai kecenderungan untuk konvergen atau saling bertemu pada satu titik. Hal ini menunjukkan keduanya berhubungan substitusi karena hubungan ini terjadi apabila extended offers yang tinggi akan meningkatkan pengaruh niat beli konsumen menggunakan T-Cash walaupun merek peritel kurang dikenal, sehingga Hipotesis 6 diterima.

Kajian managerial yang dapat diberikan yaitu mengintegrasi faktor information richness, retailer brand, extended offers secara simultan. Gabungan antara penambahan konten layanan produk T-Cash dengan value penggunaan $\mathrm{T}$-Cash mendukung GNNT dapat menjadi salah satu opsi. Selain itu, memperluas jaringan kerjasama dengan peritel pada level mikro dan menengah juga dianjurkan, serta penerapan konsep one-stopshopping untuk melakukan segala transaksi dalam satu gerai peritel menggunakan T-Cash, misal membeli token listrik dan membeli produk rumah tangga sekaligus dalam satu tempat menggunakan T-Cash. Kajian managerial ini diberikan berdasarkan analisis pribadi peneliti tanpa proses validasi.

\section{KESIMPULAN DAN SARAN}

\section{A. Kesimpulan}

Penelitian ini bertujuan untuk menjawab rumusan masalah mengenai niat beli konsumen menggunakan $\mathrm{T}$-Cash yang dipengaruhi oleh information richness, retailer brand, dan extended offers, serta pengaruh hubungan komplemen dan substitusi antara ketiganya. Lima dari enam hipotesis diterima, penelitian ini menunjukkan bahwa 3 faktor yang diteliti dapat menggambarkan kondisi sebenarnya sebanyak $60 \%$.

1) Information richness, retailer brand, dan extended offers berpengaruh positif terhadap niat beli konsumen menggunakan T-Cash, dengan retailer brand berpengaruh paling besar.

2) Information richness berkomplemen dengan extended offers dalam meningkatkan niat beli konsumen menggunakan T-Cash. Extended offers berhubungan substitusi dengan retailer brand dalam meningkatkan niat beli konsumen menggunakan T-Cash. Information richness dengan retailer brand tidak berkomplemen dalam meningkatkan niat beli konsumen menggunakan T-Cash, melainkan keduanya memilki kecenderungan hubungan substitusi. Hal ini menjadi temuan baru dan berkontribusi seara teoretis dan praktis.

\section{B. Saran}

Penelitian ini memiliki keterbatasan yang dapat dijadikan saran untuk mengembangkan penelitian selanjutnya. Berikut adalah limitasi dan saran untuk pengembangan literatur.

1) Convenience sampling method dilakukan di kota metropolis Surabaya, sehingga sulit digeneralisasi pada area lain yang belum familiar terhadap e-money [1]. Disarakan agar penelitian selanjutnya memperluas area geografis.

2) Penelitian ini fokus pada peritel yang bekerjasama dengan Telkomsel di industri makanan dan hiburan untuk mewakili experiential product. Selain kedua industri tersebut, T-Cash melayani pengisian pulsa, pembayaran tagihan listrik, serta transaksi jual beli online. Disarankan agar mengembangkan jenis peritel atau merchant pada industri lain untuk memberikan kontribusi yang beragam dan lebih luas. 
3) Penelitian ini fokus pada pengaruh hubungan information richness, retailer brand, dan extended offers terhadapa niat beli konsumen menggunakan T-Cash. Disarankan penelitian selanjutnya meneliti pengaruh faktor lain, seperti convenience, perceived risk, perceived trust, serta kemungkinan adanya pengaruh interaksi antar faktor terhadap niat beli konsumen,

\section{DAFTAR PUSTAKA}

[1] W. M.-Y. Teoh, S. C. Chong, B. Lin and J. W. Chua, "Factors affecting consumers' perception of electronic payment: an empirical analysis," Internet Research, vol. 23, no. 4, pp. 465-485, 2013.

[2] A.-C. Teo, G. W.-H. Tan, K.-B. Ooi, T.-S. Hew and K.-T. Yew, "The effects of convenience and speed in m-payment," Industrial Management \& Data Systems, vol. 115, no. 2, pp. 311-331, 2015.

[3] F. Liébana-Cabanillas, J. Sánchez-Fernández and F. Muñoz-Leiva, "Antecedents of the adoption of the new mobile payment systems: The moderating effect of age," Computers in Human Behavior, vol. 35, no. June, pp. 464-478, 2014.

[4] C. Phonthanukitithaworn, C. Sellitto and M. W. Fong, "An investigation of mobile payment (m-payment) services in Thailand," Asia-Pacific Journal of Business Administration, vol. 8, no. 1, pp. 37-5, 2016.

[5] Y.-S. Yen, "The interaction effect on customer purchase intention in ecommerce," Asia Pacific Journal of Marketing and Logistics, vol. 26, no. 3, pp. 472-493, 2014.

[6] P. Kotler and G. Armstrong, Prinsip-prinsip Pemasaran, 12 ed., Jakarta: Erlangga, 2008.

[7] J. Kim, K. Yang and B. Y. Kim, "Online retailer reputation and consumer response: examining cross cultural differences," International Journal of Retail \& Distribution Management, vol. 41, no. 9, pp. 688-705, 2013.

[8] M.-C. Pan, C.-Y. Kuo, C.-T. Pan and W. Tu, "Antecedent of purchase intention: online seller reputation, product category and surcharge," Internet Research, vol. 23, no. 4, pp. 207-522, 2013.

[9] M. d. 1. P. T.-R. M. M. Orozco-Gómez, "Brand personality and purchase intention," European Business Review, vol. 27, no. 5, pp. 462-476, 2015.

[10] A. Wang and C. Lin, "Effects of content class with endorsement and information relevancy on purchase intention," Management Research Review, vol. 34, pp. 417-435, 2011.

[11] L. Zhang and M. Su, "Effects of new product preannouncement on purchase intention," Nankai Business Review International, vol. 2, no. 1, pp. 48-63, 2011.

[12] S. Oh, Y. Kim, C. Lee, G. Shim, M. Park and H. Jung, "Consumer adoption of virtual stores in Korea: focusing on the role of trust and playfulness," Psychology \& Marketing, vol. 26, no. 7, pp. 652-668, 2009.

[13] D. Y. K. Tong, K. P. Lai and X. F. Tong, "Ladies' purchase intention during retail shoes sales promotions," International Journal of Retail \& Distribution Management, vol. 40, no. 2, pp. 90-108, 2012.

[14] M. Lee, C. Cheung and Z. Cheng, "Understanding user acceptance of multimedia messaging services: an empirical study," Journal of the American Society for Information Science and Technology, vol. 24, no. 1, pp. 2066-2077, 2007.

[15] I. Hong and H. Cho, "The impact of consumer trust on attitudinal loyalty and purchase intentions in B2C e-marketplaces: intermediary trust vs seller trust," International Journal of Information Management, vol. 31, no. 5, pp. 469-479, 2011.

[16] A. O'Cass and J. Carlson, "An empirical assessment of consumers' evaluations of web site service quality: conceptualizing and testing a formative model," Journal of Services Marketing, vol. 26, no. 6, pp. 419434, 2012.

[17] S. Burt and K. Davies, "From the retail brand to the retailer as a brand: themes and issues in retail branding research," International Journal of Retail \& Distribution Management, vol. 38, no. 11/12, pp. 865-878, 2010.

[18] J. Kim and S. Lennon, "Effects of reputation and website quality on online consumers' emotion, perceived risk and purchase intention: based on the stimulus-organism-response model," Journal of Research in Interactive Marketing, vol. 7, no. 1, pp. 33-56, 2013.
[19] N. Yasin, M. Noor and O. Mohamad, "Does image of country-of-origin matter to brand equity?," Journal of Product \& Brand Management, vol. 16, no. 1, pp. 38-48, 2007.

[20] O. Mascarenhas, R. Kesavan and M. Bernacchi, "Lasting customer loyalty: a total customer experience approach," Journal of Consumer Marketing, vol. 23, no. 7, pp. 397-405, 2006.

[21] H.-C. Huang, Y.-T. Chang, C.-Y. Yeh and C.-W. Liao, "Promote the price promotion," International Journal of Contemporary Hospitality Management, vol. 26, no. 7, pp. 1065 - 1082, 2014.

[22] Y. Wan, M. Nakayama and N. Sutcliffe, "The impact of age and shopping experiences on the classification of search, experience, and credence goods in online shopping," Information Systems \& e-Business Management, vol. 10, no. 1, pp. 135-148, 2012.

[23] D. Jang and A. Mattila, "An examination of restaurant loyalty programs: what kinds of rewards do customers prefer?," International Journal of Contemporary Hospitality Management, vol. 17, no. 5, pp. 402-408, 2005.

[24] S. Persada, S. Lin, R. Nadlifatin and M. Razif, "Investigating the citizens' intention level in environmental impact assessment participation through an extended theory of planned behavior model," Global NEST Journal, vol. 17, no. 4, pp. 847-857, 2015.

[25] H. Guo, S. C. Lee, W. M. Li and J. J. Cao, "Source characterization of BTEX in indoor microenvironments in Hong Kong," Atmospheric Environment, vol. 37, no. 1, pp. 73-82, 2003.

[26] S.-C. Lin, S. F. Persada and R. Nadlifatin, "A Study of Student Behavior in Accepting the Blackboard Learning System: a Technology Acceptance Model (TAM) Approach," Taipei, 2014.

[27] E. Conway, N. Fu, K. Monks, K. Alfes and C. Bailey, "Demands or Resources? The Relationship Between HR Practices, Employee Engagement, and Emotional Exhaustion Within a Hybrid Model of Employment Relations," Human Resource Management, vol. 55, no. 5, p. 901-917, 2015. 